\title{
Time-resolved laser flash photolysis study on transient reaction between excited triplet state of anthraquinone derivatives (AQS) and 2-deoxythymidine
}

\author{
Jianhua Ma \\ Department of Materials Science and Engineering, Xiamen Institute of Technology, Huaqiao University, Xiamen, China; \\ jianhuam1957@126.com
}

Received 27 April 2013; revised 27 May 2013; accepted 4 June 2013

Copyright (c) 2014 Jianhua Ma. This is an open access article distributed under the Creative Commons Attribution License, which permits unrestricted use, distribution, and reproduction in any medium, provided the original work is properly cited. In accordance of the Creative Commons Attribution License all Copyrights (C) 2014 are reserved for SCIRP and the owner of the intellectual property Jianhua Ma. All Copyright (C) 2014 are guarded by law and by SCIRP as a guardian.

\section{ABSTRACT}

The transient absorption spectra and kinetics of excited triplet state of anthraquinone derivatives 2-anthraquinonesulfonatesodium (AQS) and 2deoxythymidine (dT) have been investigated in $\mathrm{CH}_{3} \mathrm{CN}-\mathrm{H}_{2} \mathrm{O}$ (97:3) using the time-resolved laser flash photolysis technique $(\mathrm{KrF}, 248 \mathrm{~nm})$. The absorption spectra of $\mathrm{dT}$ radical cation and the radical anion of AQS have been observed. From dynamic and thermodyrnamic analysis, the mechanism of this transient reaction has been initially analysed.

\section{KEYWORDS}

\section{2-Anthraquinonesulfonatesodium (AQS); 2-Deoxythymidine; Transient Reaction; Laser Flash Photolysis}

\section{INTRODUCTION}

Quinones play central roles in aerobic respiration and energy-yielding photosynthesis [1]. The "strong sensitizer” 2-anthraquinonesulfonatesodium (AQS), has received much attention because of its relevance to some important photosensitizing effects induced by anthraquinones, phototendering of cellulosic materials. Recently, interest in photobiology area has been heightened by suggestions for utilizing anthraquinones as photonuclease [2]. AQS is a strong sensitizer and for numerous investigations concerning on it [3-5], only a few studies have been performed on the reaction of AQS with biological substances [5]. Here we report that time-resolved spectros- copic and kinetic evidences for the interaction of AQS with $\mathrm{dT}$ in $\mathrm{CH}_{3} \mathrm{CN}-\mathrm{H}_{2} \mathrm{O}$ solvent mixture were investigated using $\mathrm{KrF}$ laser flash photolysis. The transient absorption spectra and kinetics obtained from electron transfer oxidation of dT by triplet AQS indicated that the produced radical ion pairs, radical cations of $\mathrm{dT}$ and radical anion of AQS, were identified simultaneously.

\section{EXPERIMENTAL}

2-Anthraquinonesulfonatesodium (AQS) (Fluka, >98\%) was recrystallized twice from triply distilled water before use. 2-Deoxythymidine (dT) was purchased from sigma. All the samples were prepared in triply distiled water and deoxygenated by bubbling with high purity nitrogen (99.99\%). All experiments were carried at room temperature. Laser flash photolysis experimental methods and the specifications of equipment ( $\mathrm{KrF}$ excimer laser: $248 \mathrm{~nm}$; pulse wide: $20 \mathrm{~ns}, 50 \mathrm{~mJ}$ ) has been described previously [6].

\section{RESULTS AND DISCUSSION}

\subsection{The Characteristic Transient Absorption Spectra of the H-Abstraction Radicals of Deoxyribonucledeotide Bases}

Figure 1 shows the transient absorption spectra at $1 \mu \mathrm{s}$ after laser photolysis of $\mathrm{N}_{2}$ saturate $\mathrm{CH}_{3} \mathrm{CN}-\mathrm{H}_{2} \mathrm{O}$ (97:3) solution containing $1 \times 10^{-4} \mathrm{~mol} \cdot \mathrm{dm}^{-3}$ deoxyribonucledeotide bases (TMP, dCMP, dGMP, dAMP) and $2 \times$ $10^{2} \mathrm{~mol} \cdot \mathrm{dm}^{-3} \mathrm{~K}_{2} \mathrm{~S}_{2} \mathrm{O}_{8}$ and $2 \times 10^{-2} \mathrm{~mol} \cdot \mathrm{dm}^{-3} \mathrm{t}-\mathrm{BuOH}$, respectively. These characterized transient absorption peaks are very similarity that reported previously [5-7], 


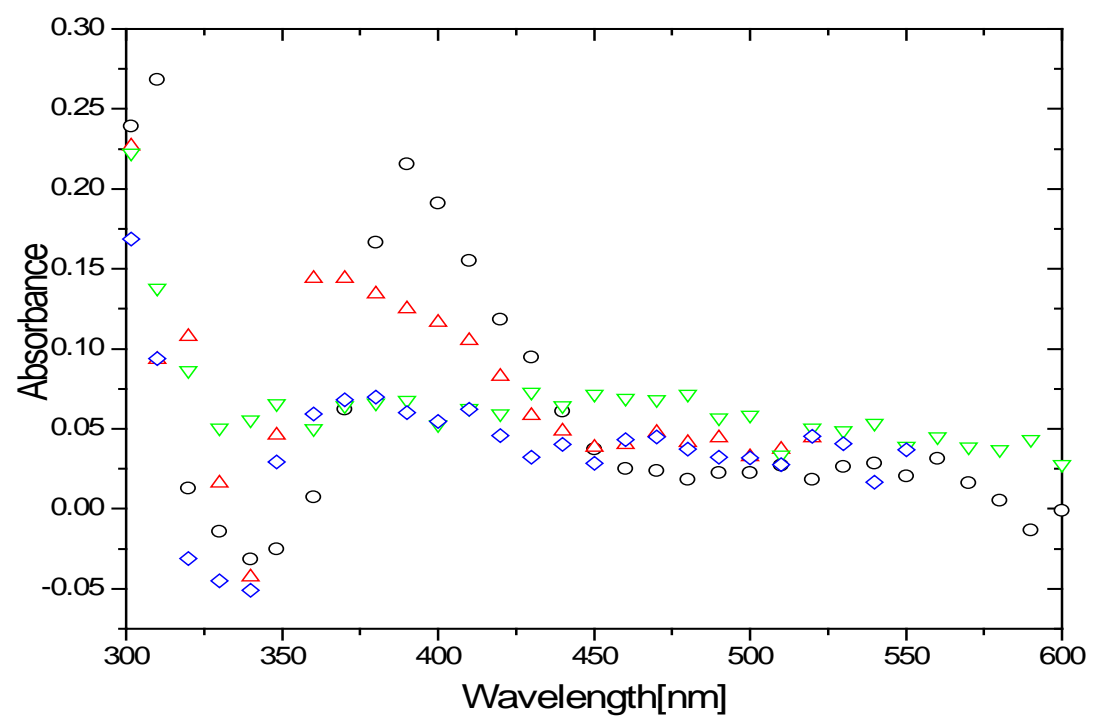

Figure 1. $\mathrm{N}_{2}$ saturate $\mathrm{CH}_{3} \mathrm{CN}-\mathrm{H}_{2} \mathrm{O}(97: 3)$ solution containing $1 \times 10^{-4} \mathrm{~mol} \cdot \mathrm{dm}^{-3}$ deoxyribonucledeotide bases (TMP, dCMP, dGMP, dAMP) and $2 \times 10^{2} \mathrm{~mol} \cdot \mathrm{dm}^{-3}$ $\mathrm{K}_{2} \mathrm{~S}_{2} \mathrm{O}_{8}$ and $2 \times 10^{-2} \mathrm{~mol} \cdot \mathrm{dm}^{-3} \mathrm{t}-\mathrm{BuOH}$. $(\diamond) \mathrm{TMP},(\boldsymbol{\nabla}) \mathrm{dCMP},(\triangle) \mathrm{dAMP},(\circ)$ dGMP, respectively. Recorded at $40 \mu$ s after laser excitetiam.

should be reasonably ascribed to the radical cation of $\mathrm{H}$ abstraction radicals of deoxyribonucledeotide bases. It is clear that the same radical cation species were produced in different experiments. For example, the one of generation of dT cation radical can be illustrated as below:

$$
\begin{gathered}
\mathrm{t}-\mathrm{BuOH}+\cdot \mathrm{OH} \rightarrow \mathrm{CH}_{2} \mathrm{C}\left(\mathrm{CH}_{3}\right)_{2} \mathrm{OH}+\mathrm{H}_{2} \mathrm{O} \\
\mathrm{e}_{\text {-aq }}+\mathrm{S}_{2} \mathrm{O}_{8}^{2-} \rightarrow \mathrm{SO}_{4}^{-}+\mathrm{SO}_{4}^{2-} \\
\mathrm{dT}+\mathrm{SO}_{4}^{-} \rightarrow \mathrm{dT}^{+}+\mathrm{SO}_{4}^{2-}+\mathrm{H}^{+}
\end{gathered}
$$

\subsection{The Transient Absorption Spectra of the Interaction of AQS with dT}

In our present paper, the characteristic transient absorption spectra of radical anion of $\mathrm{AQS}\left(\mathrm{AQS}^{-}\right)$and triplet AQS $\left({ }^{3} \mathrm{AQS}^{*}\right)$ are from laser photolysis in deaerated $\mathrm{CH}_{3} \mathrm{CN}-\mathrm{H}_{2} \mathrm{O}$ (97:3) solution have been repored, and the spectrum characterized at $510 \mathrm{~nm}$ and $380 \mathrm{~nm}$, $470 \mathrm{~nm}, 580 \mathrm{~nm}$ have assigned to radical anion of AQS (AQS ${ }^{-}$) and triplet AQS $\left({ }^{3} \mathrm{AQS}^{*}\right)$, respectively [8].

Figure 2 shows transient absorption spectra from laser photolysis of $0.028 \mathrm{AQS} \mathrm{mmol} \cdot \mathrm{dm}^{-3}$ and $0.05 \mathrm{mmol} \cdot \mathrm{dm}^{-3}$ dT in $\mathrm{CH}_{3} \mathrm{CN}-\mathrm{H}_{2} \mathrm{O}$ (97:3) solution, saturated with $\mathrm{N}_{2} \mathrm{O}$. After the pulse, an absorption band characterized at 510 $\mathrm{nm}$ and decays by second order kinetics, which is similar to that of the radical anion of AQS reported previously [8], and should be assigned to AQS ${ }^{-}$. The late transient absorption characterized rang $350 \mathrm{~nm}-450 \mathrm{~nm}$, should be reasonably ascribed to the radical cation of dT-H due to its similarity to that the radical cation of dT in Figure 1 and photoinization of deoxyribonucleotide $[8,9]$. The growth trace of transient species at $510 \mathrm{~nm}$ was occurred exactly in the same time interval as did the AQS triplet decay at $580 \mathrm{~nm}$ (Figure 3), which decayed following first-order kinetics, and it is the net contribution of triplet AQS $\left({ }^{3} \mathrm{AQS}^{*}\right)$, as shown Figure 4.

So we implying that the AQS triplet state is the precursor of the radical anion and transient species at 350 $\mathrm{nm}-450 \mathrm{~nm}$, revealing the feature of $\mathrm{dT}^{+}$characterized. It is evident that ${ }^{3} \mathrm{AQS}^{*}$ was quenched by $\mathrm{dT}$ via electron transfer producing long lived $\mathrm{dT}^{+}$species.

\subsection{The kinetic Parameters of Transient Species and Free Energy Change $(\Delta G)$ of Electron Transfer between AQS and $\mathrm{dT}$}

In the reaction of electron transfer between AQS and $\mathrm{dT}$, the formation trace of $\mathrm{dT}^{+}$at $360 \mathrm{~nm}$ can be obtained by subtracting the absorbance at $580 \mathrm{~nm}$ multiplied by $\mathrm{A}^{360} / \mathrm{A}^{580}$ from that at $360 \mathrm{~nm}$. At mean time, the formation trace of $\mathrm{AQS}^{-}$at $510 \mathrm{~nm}$ can be obtained by subtracting the absorbance at $580 \mathrm{~nm}$ multiplied by $\mathrm{A}^{510}$ / $\mathrm{A}^{580}$ from that at $510 \mathrm{~nm}$ too. The corresponding kinetic parameters of transient species growth at $360 \mathrm{~nm}, 510$ $\mathrm{nm}$ and triplet AQS decay at $580 \mathrm{~nm}$ are $1.2 \times 10^{9}$ $\mathrm{dm}^{3} \cdot \mathrm{mol}^{-1} \cdot \mathrm{s}^{-1}, 1.6 \times 10^{9} \mathrm{dm}^{3} \cdot \mathrm{mol}^{-1} \cdot \mathrm{s}^{-1}$ and $1.5 \times 10^{9}$ $\mathrm{dm}^{3} \cdot \mathrm{mol}^{-1} \cdot \mathrm{s}^{-1}$, respectively. Obviously, the formation rate constants of radical cations of $\mathrm{dT}$ and radical anion of AQS are nearly equal to that of decay of triplet AQS respectively. On the other hand, The $\Delta \mathrm{G}$ (free energy changes) for the electron transfer of between triplet AQS and $\mathrm{dT}$ can be calculated according to the Rehm-Weller equation and the $\mathrm{E}_{\mathrm{ox}}$ values of $\mathrm{dT}$ was calculated via an 


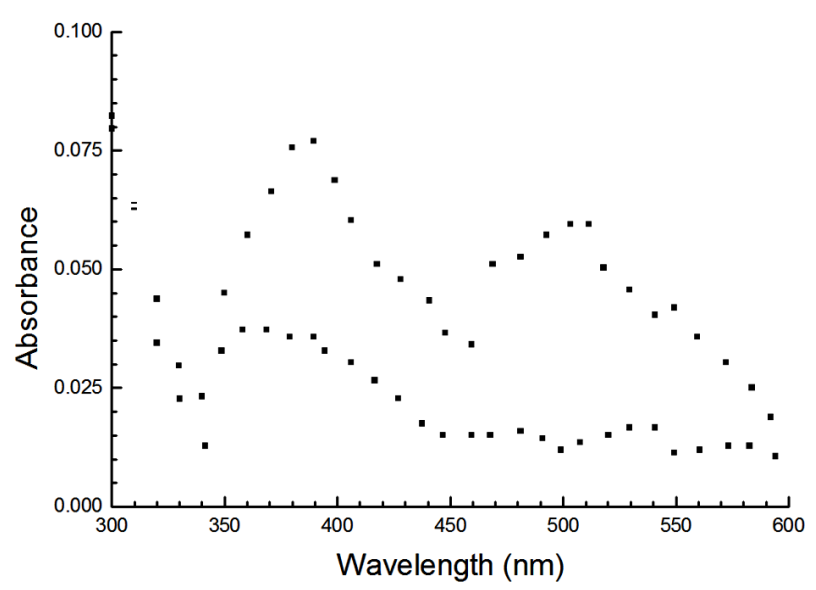

Figure 2. Transient absorption spectra from laser photolysis of $0.028 \mathrm{mmol} \cdot \mathrm{dm}^{-3} \mathrm{AQS}$ and $0.05 \mathrm{mmol} \cdot \mathrm{dm}^{-3} \mathrm{dT}$ in $\mathrm{CH}_{3} \mathrm{CN}-$ $\mathrm{H}_{2} \mathrm{O}(97: 3)$ solution, saturated with $\mathrm{N}_{2} \mathrm{O}$. (口) $1 \mu \mathrm{s}$, (घ) $25 \mu \mathrm{s}$.

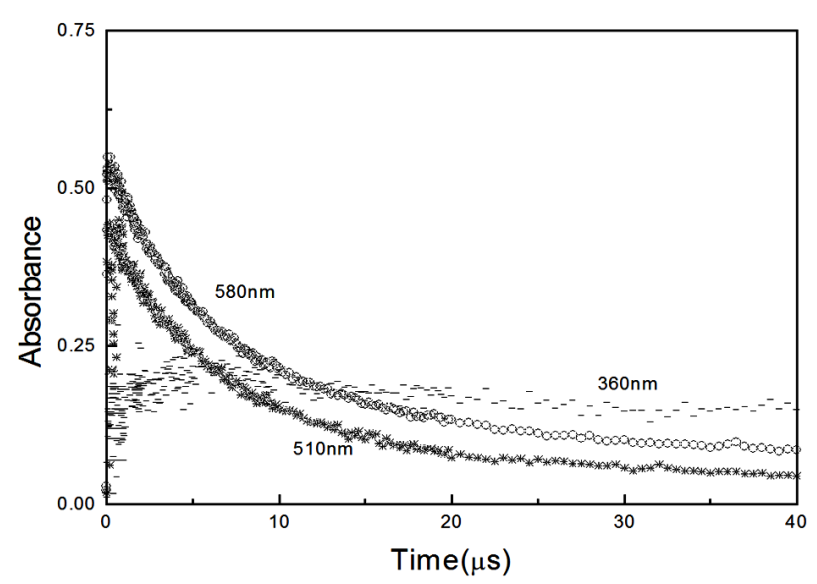

Figure 3. Decay and growth curves of mixed solution of 0.028 $\mathrm{mmol} \cdot \mathrm{dm}^{-3}$ AQS and $0.05 \mathrm{mmol} \cdot \mathrm{dm}^{-3} \mathrm{dT}$ at $580 \mathrm{~nm}, 510 \mathrm{~nm}$ and $360 \mathrm{~nm}$.

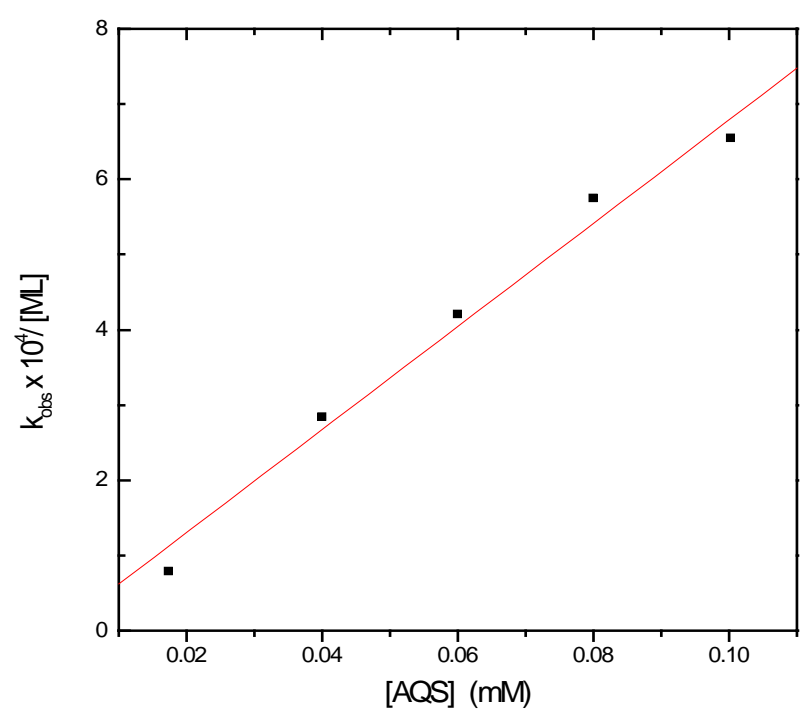

Figure 4. Plot of the apparent decay rate constant of ${ }^{3} \mathrm{AQS}^{*}$. empirical equation $\mathrm{E}_{\mathrm{ox}}=0.89 \mathrm{IP}-6.04$ [10], and the $\mathrm{E}_{\text {red }}$ (AQS, vs. SCE), $\Delta \mathrm{E}_{0,0}, \Delta \mathrm{G}$ (energy of ${ }^{3} \mathrm{AQS}^{*}$ ), $\mathrm{e}^{2} / \varepsilon \mathrm{d}$ and the coulombic term are published results [11-14], respectively. From these, free energy change $(\Delta \mathrm{G})$ value $(\mathrm{KJ} /$ mol) was calculated as $\mathrm{dT}-68.3 \mathrm{KJ} / \mathrm{mol}$. It means that the electron transfer oxidation reactions between triplet AQS and dT is exothermic.

From the above results, these experimental findings provide reliable evidence for the electron transfer oxidation reactions between triplet AQS and dT. The predominant initial species from electron transfer oxidation of $\mathrm{dT}$ is $\mathrm{dT}$ radical cation. The proposed reaction mechanism of generation of the $\mathrm{dT}$ radical cation and the radical anion of AQS can be presented as follows:

$$
\begin{aligned}
& \text { hv ISC } \\
& \mathrm{AQS} \rightarrow \mathrm{AQS}^{*} \rightarrow{ }^{3} \mathrm{AQS}^{*} \\
& { }^{3} \mathrm{AQS}^{*}+\mathrm{dT} \rightarrow \mathrm{AQS}^{-}+\mathrm{dT}^{+}
\end{aligned}
$$

\section{CONCLUSION}

The transient absorption spectra of interaction of triplet AQS with dT were observed and the rate constants for formation of radical cation of $\mathrm{dT}$ and those of radical anion of AQS and the decay of triplet AQS were also determined. The time resolved evidence of dynamic and thermo-dynamic of laser spectra and kinetics of radical ion pairs from electron transfer oxidation of dT by triplet AQS were provided.

\section{ACKNOWLEDGEMENTS}

This project was supported by the Education Committee of Fujian Province, China (JA13593S).

\section{REFERENCES}

[1] Zhang, S.M., Han, S.T. and Liu, Y.H. (2004) Progress of study on photonuclease-anthraquinone derivatives. Journal Hebei Normal University, 3, 27-30.

[2] David, T., Breslin, D.T., Coury, J.R., et al. (1997) Anthrquinone photonuclease structure determines its mode of binding to DNA and the cleavage chemistry observed. Journal of America Chemistry Society, 119, 5043-5045. http://dx.doi.org/10.1021/ja963607h

[3] Ma, J.H., Lin, W.Z., Wang, W.F., Han, Z.H., Yao, S.D. and Lin, N.Y. (1999) Characterization of reactive intermediates in laser photolysis of nucleoside using sodium salt of 9,10-anthrax-quinone-2-sulfonate as photosensitizer. Radiation Physics and Chemistry, 54, 337-340. http://dx.doi.org/10.1016/S0969-806X(98)00300-4

[4] Loeff, A., Treinin, H. and Linsckitz H. (1983) Photochemistry of 9,10-anthraquinone-2-sulfonate in solution. 1. Intermediates and mechanism. Journal of Physics and Chemistry, 87, 2536-2540. http://dx.doi.org/10.1021/j100237a017

[5] Loeff, J., Rabani, A., Treinin, H. and Linschitz H. (1993) Charge transfer and reactivity of $n \pi^{*}$ and $\pi \pi^{*}$ organic 
triplets, including anthraquinonesulfonates, in interactions with inorganic anion: A comparative study based on classical Marcus theory. Journal of America Chemistry Society, 115, 8933-8937.

http://dx.doi.org/10.1021/ja00073a007

[6] Ma, J.H., Lin, W.Z., Wang, W.F., Han, Z.H., Yao, S.D. and Lin, N.Y. (2002) Laser photolysis of interaction of poly-guanylic acid (5') with anthraquinone-2-sulfonate. Science in China, 45, 384-387.

[7] Candeias, L.P. and Steenken, S. (1993) Electron transfer in di(deoxy)nucleoside phosphates in aqueous solution: Rapid migration of oxidation damage (via adenine) to guanine. Journal of America Chemistry Society, 115, 24372441. http://dx.doi.org/10.1021/ja00059a044

[8] Ma, J.H., Lin, W.Z., Han, Z.H., Yao, S.D. and Lin, N.Y. (2006) Electron transfer reaction between desoxyadenosine and triplet 2-methyl-1,4-naphthaquinone: A laser photolysis study. Chemistry Research Chinese University, 22, 397-341. http://dx.doi.org/10.1016/S1005-9040(06)60126-8

[9] Rehm, D. and Weller, D. (1970) Kinetics of fluorescence quenching by electron and hydrogen-atom transfer. Israel Journal of Chemistry, 8, 259-262. http://dx.doi.org/10.1002/ijch.197000029
[10] Miller, L.L., Nordblum, G.B. and Mayeda, E.A. (1972) A simple comprehensive correlation of organic oxiation and ionization potentials. Journal of Organic Chemistry, 37, 916-919. http://dx.doi.org/10.1021/jo00971a023

[11] Nikogosyan, D.N. (1990) Two-quantum UV photochemistry of nucleic acids: Comparison with conventional lowintensity UV photochemistry and radiation chemistry. International Journal of Radiation Biology, 57, 233-236. http://dx.doi.org/10.1080/09553009014552411

[12] Colson, A.O., Beslter, B., Close, D.M. and Sevilla, M.D. (1992) Ab initio molecular orbital calcuiations of DNA bases and their radical ions in various protonation states: Evidence for proton transfer in GC base pair radical anions. Journal of Physical Chemistry, 96, 661-668. http://dx.doi.org/10.1021/j100181a028

[13] Loeff, I., Rabani, J. and Linschitz, H. (1993) Charge transfer and reactivity of $n \pi *$ and $\pi \pi^{*}$ organic triplets, including anthraquinonesulfonates, in interactions with inorganic anion: A comparative study based on classical Marcus theory. Journal of America Chemistry Society, 115, 8933-8942. http://dx.doi.org/10.1021/ja00073a007

[14] Fox, M.A. and Chanon, M. (1988) Photoinduced electron transfer. Elsevier, Amsterdam, 48-192. http://library.wur.nl/WebQuery/clc/512801 